\title{
Article
}

Mycosphere

\section{Comparative studies on glucanases and $\beta$-glucosidase activities of Pleurotus ostreatus and $P$. pulmonarius in solid state fermentation}

\author{
Ekundayo FO $^{1 *}$, Ekundayo EA ${ }^{2}$ and Ayodele BB ${ }^{1}$ \\ ${ }^{l}$ Department of Microbiology, Federal University of Technology, Akure, Nigeria \\ ${ }^{2}$ Department of Biological Sciences, Afe Babalola University, Ado-Ekiti, Nigeria
}

Ekundayo FO, Ekundayo EA, Ayodele BB 2017 - Comparative studies on glucanases and $\beta$ glucosidase activities of Pleurotus ostreatus and P. pulmonarius in solid state fermentation. Mycosphere 8(8), 1051-1059, Doi 10.5943/mycosphere/8/8/12

\begin{abstract}
Agricultural wastes constitute major environmental problem. However, these wastes can be used as substrates for the production of enzymes such as cellulases by filamentous fungi including Pleurotus species. This present investigation was therefore aimed at screening Pleurotus ostreatus DBUI 14 and $P$. pulmonarius DBUI002 for glucanases and $\beta$-glucosidase using rice bran, corn cob and sawdust as substrates. Both P. ostreatus DBUI14 and P. pulmonarius DBUI002 cultivated on pretreated rice bran, corn cob and sawdust were screened for cellulolytic enzymes under solid state fermentation (SSF) for a period of 15 days using standard methods. The protein contents were determined using the method of Lowry. The results showed that lowest activities of these enzymes by Pleurotus spp occurred on the third and fifteenth days while the highest activities occurred on the ninth day of fermentation. The highest endoglucanase as well as lowest exoglucanase activities were obtained from Pleurotus pulmonarius DBUI002cultivated on corn cob (PPCC). Pleurotus ostreatus DBUI 14 cultivated on corn cob (POCC) had the lowest endoglucanase but highest exoglucanase activity when grown on rice bran (PORB). Moreover, lowest $\beta$-glucosidase activity was obtained from POCC while PPCC and PORB had the highest $\beta$-glucosidase activities. Pleurotus pulmonarius cultivated on corn cob and $P$. ostreatus cultivated on rice bran could be harnessed in the commercial production of endoglucanase and exoglucanase. In addition, both Pleurotus ostreatus DBUI 14 strain and $P$. pulmonarius DBUI002 could be harnessed in synthesis of $\beta$-glucosidase.
\end{abstract}

Key words - agro-industrial wastes bioconversion extracellular cellulolytic enzymes - pretreatment - submerged fermentation

\section{Introduction}

Most often than not disposal of agro-industrial wastes constitutes a major environmental problem in developing countries (Khalil 2002, Göğüş et al. 2014). Bioconversion of these wastes to useful substances requires activities of enzymes, namely, $\beta-1,4$ glucanases, $\beta$ - 1,4 exoglucanase and $\beta$ 1,4 glucosidase, pectinases etc (Baker et al. 1995, Mansfield et al. 1998, Birhanlı \& Yeşilada 2013, Gögüş et al. 2014). It is advantageous to produce enzymes using microorganisms since they are not influenced by climatic and seasonal factors and can be subjected to genetic and environmental manipulations to increase product yield (Dhillon et al. 2004). The genera Trichoderma and 
Aspergillus have been extensively used in the production of cellulolytic enzymes (Baig 2005, Narasimha et al. 2006).

Extracellular cellulolytic enzymes can also be produced from macrofungi which are known to be safe. Pleurotus spp. have been found to be efficient in utilizing agricultural residues (Zhang et al. 2002, Salmones et al. 2005, Alborés et al. 2006). Goyal \& Sony (2011) reported that cellulolytic enzymes were produced by $P$. florida, $P$. ostreatus and $P$. sajar-caju but highest production was by $P$. florida. The major methods used in production of cellulolytic enzymes by fungi are solid state fermentation (SSF) and submerged culture of the microorganisms (Lonsane \& Ghildyal 1993, Ishida et al. 2006). However, it is very expensive to produce cellulolytic enzymes by submerged fermentation (Ruth et al. 1999). The importance of solid state fermentation over submerged fermentation cannot be underestimated. The cost of producing cellulolytic enzymes via SSF is low and the yield is high. Also, energy consumed is low, it is simple to carry out and a little waste product is generated (Gupte \& Madamwar 1997). Moreover, cellulolytic enzymes produced by SSF are more concentrated in the culture filtrate (Moo-Young et al. 1983). The present work was therefore aimed at determining cellulolytic enzymes by $P$. ostreatus and $P$. pulmonarius using corn cob, saw dust and rice bran as substrates using solid state fermentation.

\section{Materials \& Methods}

\section{Collection of materials}

Pleurotus ostreatus DBUI 14 and P. pulmonarius DBUI002 were collected from the Department of Botany, University of Ibadan, Oyo State, Nigeria and were used for spawn preparation and mass production of the selected mushrooms. These cultures were cultivated and preserved at $4^{\circ} \mathrm{C}$ on potato dextrose agar respectively.

The agro-industrial substrates namely rice bran, corn cob and sawdust of Hannoa klaineana were obtained from market and timber shed at Akure, Ondo State, Nigeria.

\section{Solid state fermentation of rice bran, corn cob and sawdust}

Pretreatment of each substrate was done by soaking in $1.0 \%(\mathrm{w} / \mathrm{v}) \mathrm{NaOH}$ solution. Five grammes of pretreated rice bran, corn cob and sawdust were placed in $250 \mathrm{~mL}$ flasks and then autoclaved at $121^{\circ} \mathrm{C}$ for 15 minutes. Both $P$. ostreatus and $P$. pulmonarius ( $1 \mathrm{~mm}$ disk) were cultivated separately in $20 \mathrm{~mL}$ of $1 \%$ carboxyl methyl cellulose (CMC) and the selected agroindustrial wastes as well as czapek dox medium $\left(\mathrm{Na}_{2} \mathrm{HPO}_{4} 1.0, \mathrm{NaNO}_{3} 3.0, \mathrm{KCl} 0.5, \mathrm{MgSO}_{4} \cdot 7 \mathrm{H}_{2} \mathrm{O}\right.$ 0.1 and $\mathrm{FeSO}_{4} \cdot 7 \mathrm{H}_{2} \mathrm{O} 0.001$ ) at $\mathrm{pH} 5.0$ after autoclaving at $121^{\circ} \mathrm{C}$ for 15 minutes. The inoculated flasks were incubated at $30^{\circ} \mathrm{C}$ in a static position for 15 days (Goyal \& Sony 2011).

\section{Extraction of Enzyme}

Twenty five millilitres of cooled $0.05 \mathrm{M}$ citrate buffer with $\mathrm{pH} 4.8$ was added to each flask at interval of three days and the filtrates were then subjected to enzyme activity to determine endoglucanase, exoglucanase and $\beta$-glucosidase production by the Pleurotus species by the dinitrosalicylic acid (DNS) method (Miller 2000) following degradation of appropriate substrate by enzyme extracts supplied from the different flasks. Each assay system contained enzyme extract, substrate and buffer using a standard assay of $0.5 \mathrm{~mL}$. After intervals of 3days incubation periods at $28^{\circ} \mathrm{C}-30^{\circ} \mathrm{C}$, reactions were terminated by the addition of the Dinitrosalicylic acid (DNS) reagent and heating for 5 minutes at $100^{\circ} \mathrm{C}$. Controls included inclusion of substrate and omission of enzyme extract (Miller 2000).

\section{Endoglucanase activity of $\boldsymbol{P}$. ostreatus and $\boldsymbol{P}$. pulmonarius}

Endoglucanase activities of both Pleurotus ostreatus DBUI14 and P. pulmonarius DBUI002 were done according to the methods described by Mandels et al. (2006). The reaction mixture consists of $1.0 \mathrm{~mL}$ of $0.05 \mathrm{M}$ citrate buffer $(\mathrm{pH} 4.8), 1.0 \mathrm{~mL}$ of $1 \% \mathrm{CMC}$ solution and $0.5 \mathrm{ml}$ of culture filtrate which was then incubated at $50{ }^{\circ} \mathrm{C}$. Determination of reducing sugars released was done by 
withdrawing $0.5 \mathrm{~mL}$ of sample at zero and 30 minutes interval and the absorbance was measured at $540 \mathrm{~nm}$ (Miller 2000).

\section{Exoglucanase activity}

Tiny pieces of Whatman no.1 filter paper were used for the determination of exoglucanase activities of Pleurotus ostreatus DBUI14 strain and P. pulmonarius DBUI002. The cut strips containing $2 \mathrm{~mL}$ of $0.05 \mathrm{M}$ citrate buffer $(\mathrm{pH} 4.8)$ and $0.5 \mathrm{~mL}$ culture filtrate were incubated at $50^{\circ} \mathrm{C}$. Determination of reducing sugars released was done at 0 and 60 min intervals by DNS method (Miller 2000). The absorbance was measured at $540 \mathrm{~nm}$.

\section{$\beta$-glucosidase activity of $P$. ostreatus and $P$. pulmonarius}

The reaction mixture consisted of $1 \%$ cellobiose solution $(1 \mathrm{~mL}), 0.05 \mathrm{M}$ citrate buffer $(0.5$ $\mathrm{mL})$ and enzyme solution $(0.5 \mathrm{~mL})$. The mixture was then incubated at $50^{\circ} \mathrm{C}$ after which the amount of reducing sugars released were measured at 0 and $15 \mathrm{~min}$ of incubation period at $540 \mathrm{~nm}$ according to DNSA method. One unit of enzyme activity was expressed as the amount of enzyme that corresponded to one micromole of reducing sugars per minute under the assay conditions, using glucose as a sugar standard.

\section{Estimation of soluble protein from $\boldsymbol{P}$. ostreatus and $\boldsymbol{P}$. pulmonarius}

Total protein was determined in culture filtrate by the method of Lowry et al. (2009) with bovine serum albumin as standard measured at $540 \mathrm{~nm}$ by spectrophotometer (Hannan electronic spectrophotometer) model. Bovine serum albumin (BSA) and distilled water served as the positive and negative controls in protein estimation.

\section{Results}

Enzymatic activities of $\boldsymbol{P}$. ostreatus and $\boldsymbol{P}$. pulmonarius on different substrates during solidstate fermentation

Typical enzyme activity occurred in the colonised substrates (rice bran, corn cob and sawdust) by the prepared by the inocula (Pleurotus ostreatus DBUI14 strain and P. pulmonarius DBUI002) and the enzymes produced were extracted from the whole colonised substrates at three days interval for fifteen days. It took about sixth to twelfth days to colonise the substrates, at which time biomass was visible on the surface of the flask. The three enzymes ( $\beta$-glucosidase, endoglucanase and exoglucanase) assayed were all present during the degradation of the substrates; rice bran, corn cob and saw dust in solid state fermentation (SSF). The lowest activities of these enzymes were between the third and sixth days. The enzymes reached the peak of their activities around ninth day of growth and then declined to the lowest activities at the fifteenth day of incubation (Figures 1, 2, and 3).

\section{Endoglucanase activities of $\boldsymbol{P}$. ostreatus and $\boldsymbol{P}$. pulmonarius on different substrates during solid state fermentation}

Pleurotus ostreatus (DBUI14) cultivated on sawdust (POSW) had the highest endoglucanase activity between third and fifteenth days of SSF. On the ninth day of fermentation, maximum endoglucanase activity $(15.0 \mu \mathrm{mol} / \mathrm{min} / \mathrm{mL})$ was recorded for POSW while the minimum (1.0 $\mu \mathrm{mol} / \mathrm{min} / \mathrm{mL}$ ) for P. ostreatus on corn cob (Figure 1).

\section{Exoglucanase activities of $\boldsymbol{P}$. ostreatus and $\boldsymbol{P}$. pulmonarius on different substrates during solid state fermentation}

Pleurotus ostreatus DBUI14 cultivated on rice bran (PORB) had the highest exoglucanase activity between third and fifteenth days. On the other hand, P. pulmonarius (DBUI002) on corn cob (PPCC) had the lowest activity of this enzyme especially on the ninth day of SSF (Figure 2). 
Beta-glucosidase activities of $\boldsymbol{P}$. ostreatus and $\boldsymbol{P}$. pulmonariuson different substrates during solid state fermentation

Pleurotus pulmonarius DBUI002 cultivated on corn cob had the highest $\beta$-glucosidase activity between the third and fifteenth days. On the ninth day of fermentation, both PPCC and PORB had the same $\beta$-glucosidase activity of $33.0 \mu \mathrm{mol} / \mathrm{min} / \mathrm{mL}$ while POCC had the lowest $\beta$-glucosidase activity (Figure 3).

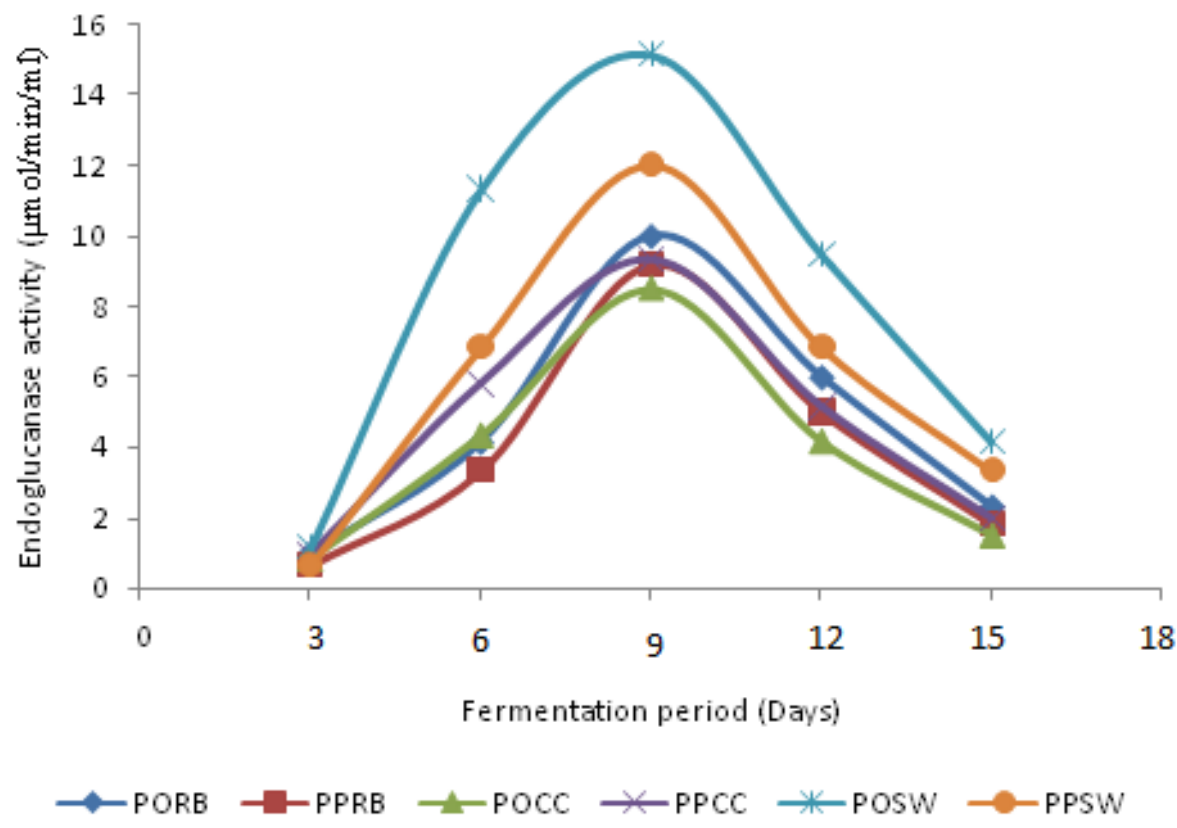

Figure 1 - Endoglucanase activities of $P$. ostreatus and $P$. pulmonarius on different substrates during solid state fermentation. PORB $-P$. ostreatus DBUI14 on rice bran; PPRB $-P$. pulmonarius DBUI002 on rice bran; PPCC - P. pulmonarius DBUI002on corn cob; POSW - P. ostreatus DBUI14 on sawdust; PPSW - P pulmonarius DBUI002 on sawdust.

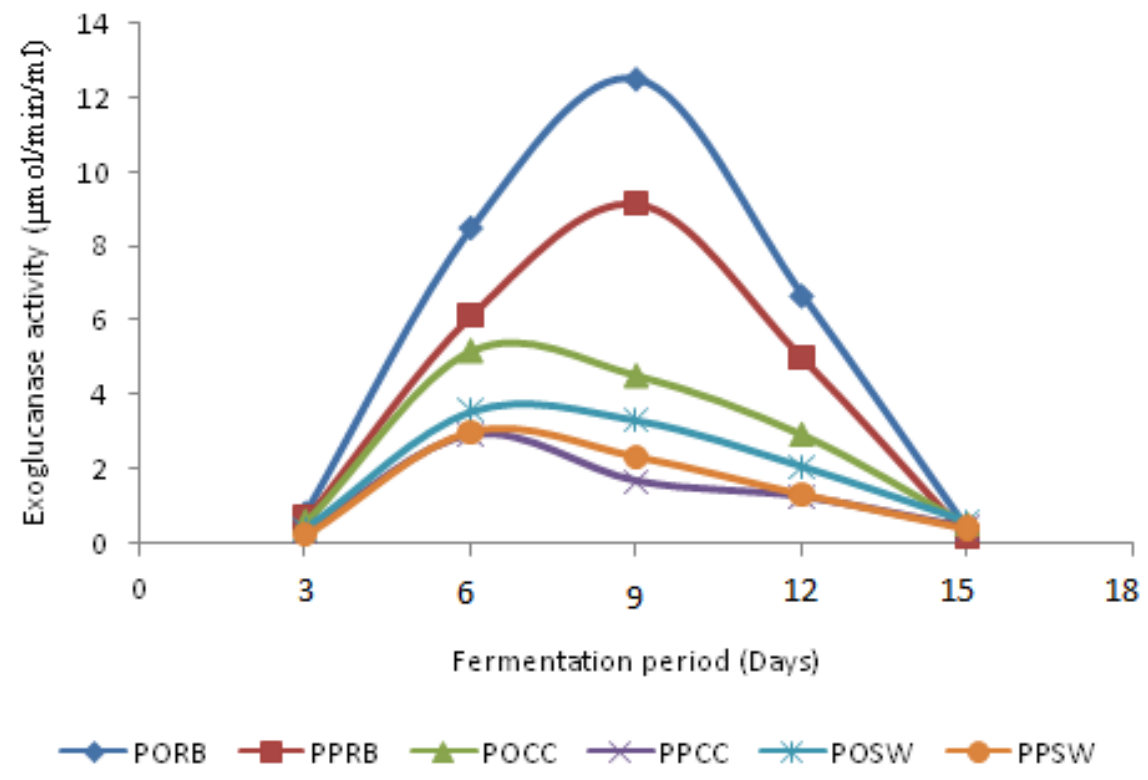

Figure 2 - Exoglucanase activities of $P$. ostreatus and $P$. pulmonarius on different substrates during solid state fermentation. PORB $-P$. ostreatus DBUI14 on rice bran; PPRB $-P$. pulmonarius DBUI002 on rice bran; PPCC - P. pulmonarius DBUI002on corn cob; POSW - P . ostreatus DBUI14 on sawdust; PPSW - P pulmonarius DBUI002 on sawdust. 


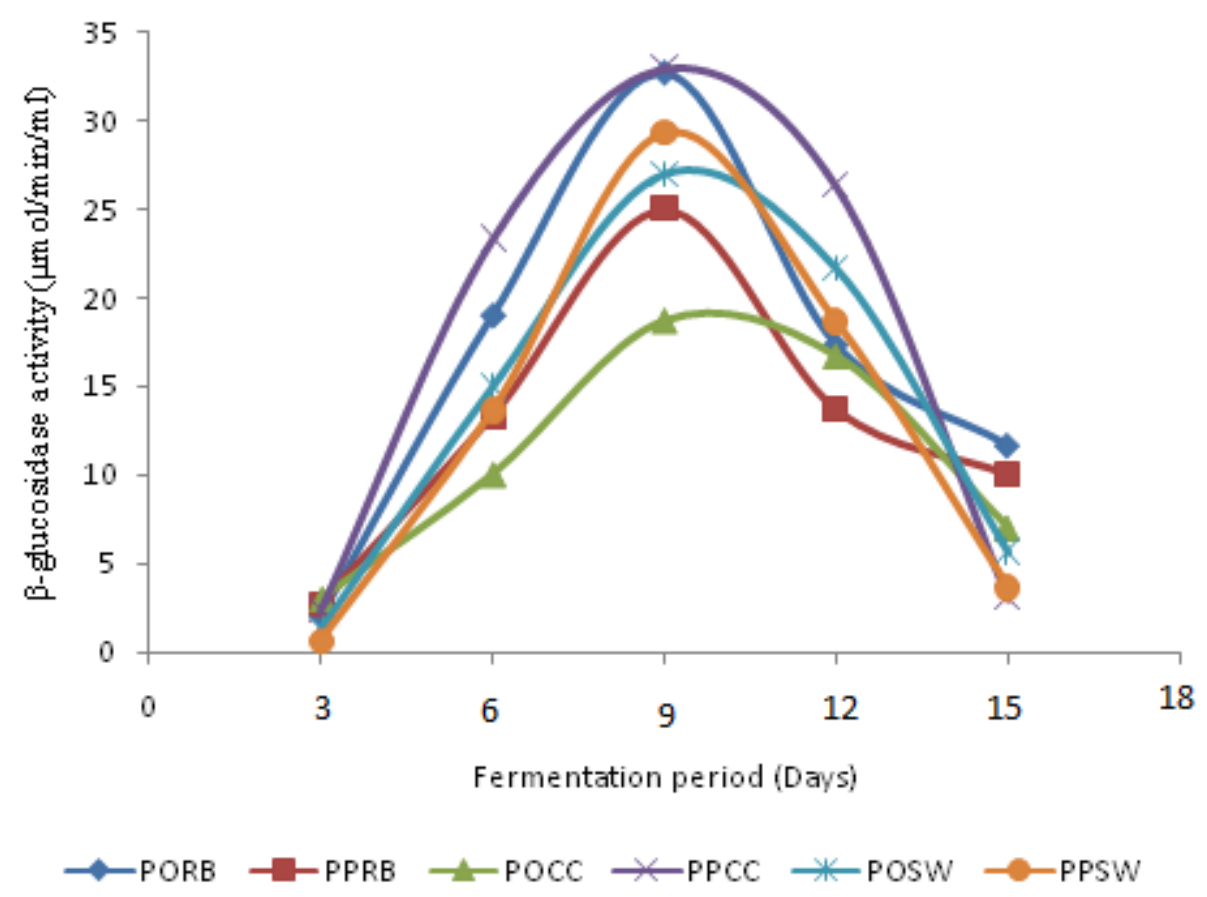

Figure 3 - $\beta$-glucosidase activities of $P$. ostreatus and $P$. pulmonarius on different substrates during solid state fermentation. PORB $-P$. ostreatus DBUI14 on rice bran; PPRB $-P$. pulmonarius DBUI002 on rice bran; PPCC - P. pulmonarius DBUI002on corn cob; POSW - P. ostreatus DBUI14 on sawdust; PPSW - P pulmonarius DBUI002 on sawdust.

\section{Soluble proteins in fermented products produced by $\boldsymbol{P}$. ostreatus and $\boldsymbol{P}$. pulmonarius}

Levels of soluble proteins of endoglucanase were found to reach a peak on the ninth day of fermentation after which the levels diminished gradually. The highest concentration of soluble protein $(6.0 \mathrm{mg} / \mathrm{mL})$ was found in P. ostreatus (DBUI14) cultivated on rice bran while the lowest level $(1.0 \mathrm{mg} / \mathrm{mL})$ was observed in P. pulmonarius (DBUI002) cultivated on sawdust (Figure 4).

Similar trends were observed for both exoglucanase and $\beta$-glucosidase. The highest concentration of soluble protein $(6.0 \mathrm{mg} / \mathrm{mL})$ was found in $P$. ostreatus (DBUI14) cultivated on rice bran while the lowest level $(0.0 \mathrm{mg} / \mathrm{mL})$ was observed in P. Pulmonarius (DBUI002) cultivated on sawdust (Figure 5). Also, the highest concentration $(9.0 \mathrm{mg} / \mathrm{mL})$ was found when rice bran was the substrate for $P$. ostreatus (DBUI14) while the lowest level $(0.5 \mathrm{mg} / \mathrm{mL}$ ) was for $P$. pulmonarius (DBUI002) when sawdust was the substrate for exoglucanase (Figure 6).

\section{Discussion}

In this study, enzymatic activities reached a peak on the ninth day of fermentation for both P. ostreatus and P. pulmonarius. Gupte \& Madamwar (1997) reported the maximum activity of lignocellulose degrading enzymes at 9-10 days of solid state fermentation (SSF). Khalil et al. (2011) reported that $P$. ostreatus and $P$. sajor-caju reached a peak on the 10 th day of fermentation. Zawistowski et al. (1991) reported the highest oxidative enzyme activity at 15 day and carboxyl methyl cellulase activity at 5-9 days on SSF of sawdust and straw in P. florida. From this research, exoglucanase, endoglucanase and $\beta$-glucosidase activities were much higher in $P$. ostreatus compared to $P$. pulmonarius. Similar results were also reported by Gupte \& Madamwar (1997) as well as Khalil et al. (2011).

The potency of $P$. ostreatus in lignocellulolytic activity over other mushrooms like Lentinus spp. has also been reported (Stamets 2000, Elisashvili et al 2008). It was found that different enzymes peaked at different fermentation period and declined subsequently which could be due to the inactivation and or degradation of these enzymes as also reported by Goyal \& Sony (2011). Cellulolytic enzymes 
produced in this present were low between 12 and 15 days of fermentation period. Hong (2006), Cai et al. (1994) and Azizi et al. (1990), reported maximum production of cellulolytic enzymes by some mushroom on 8th and 12th day of the fermentation period. Both endoglucanase and exoglucanase showed the same activity pattern but with different increasing pattern in which $\beta$-glucosidase has highest activity followed by endoglucanase and exoglucanase. Likewise, $\beta$-glucosidase showed maximum production at the 9 days of fermentation period and a slightly low production was achieved on 12-15 day of fermentation. Bisaria et al. (2008) detected higher cellulolytic enzymes production from $P$. sajocaju by using treated cotton. In this study, protein reached the maximum peak at 9 days of fermentation.

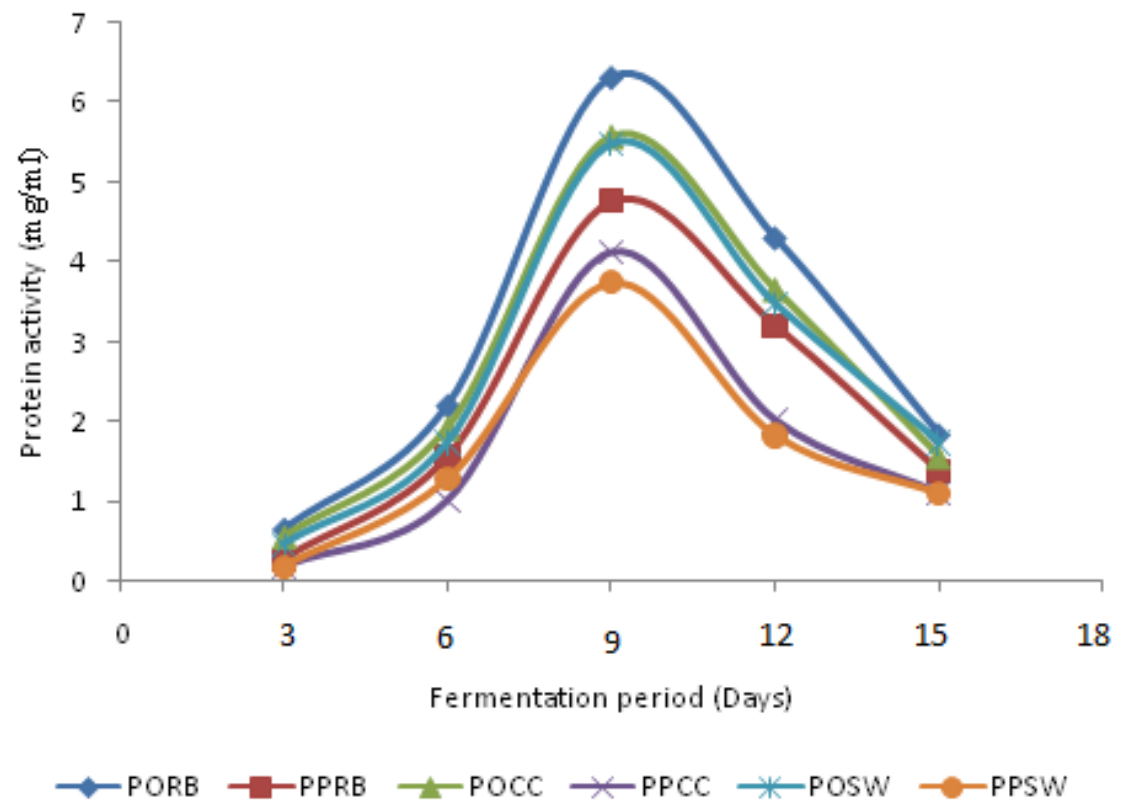

Figure 4 - Time course of protein activity of endoglucanase on selected agro-industrial wastes. PORB - P. ostreatus DBUI14 on rice bran; PPRB $-P$. pulmonarius DBUI002 on rice bran; PPCC $P$. pulmonarius DBUI002on corn cob; POSW $-P$. ostreatus DBUI14 on sawdust; PPSW $-P$ pulmonarius DBUI002 on sawdust.

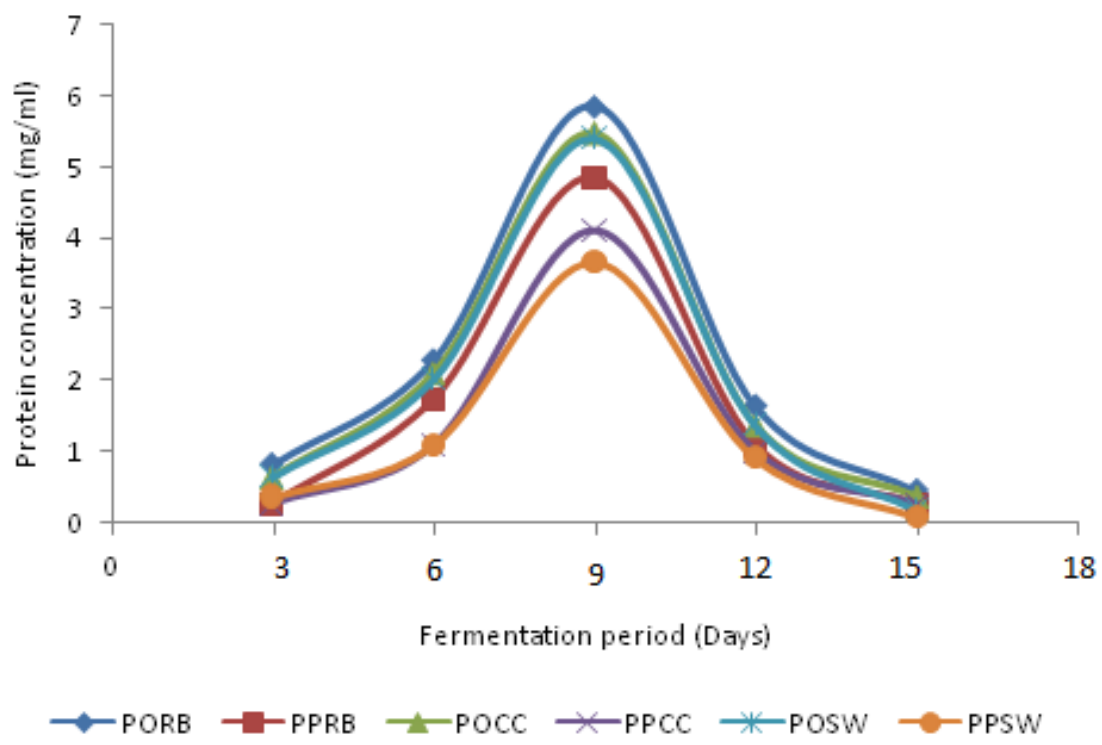

Figure 5 -Time course of protein activity of exoglucanase on selected agro-industrial wastes. PORB $-P$. ostreatus DBUI14 on rice bran; PPRB $-P$. pulmonarius DBUI002 on rice bran; PPCC $-P$. pulmonarius DBUI002on corn cob; POSW $-P$. ostreatus DBUI14 on sawdust; PPSW $-P$ pulmonarius DBUI002 on sawdust. 


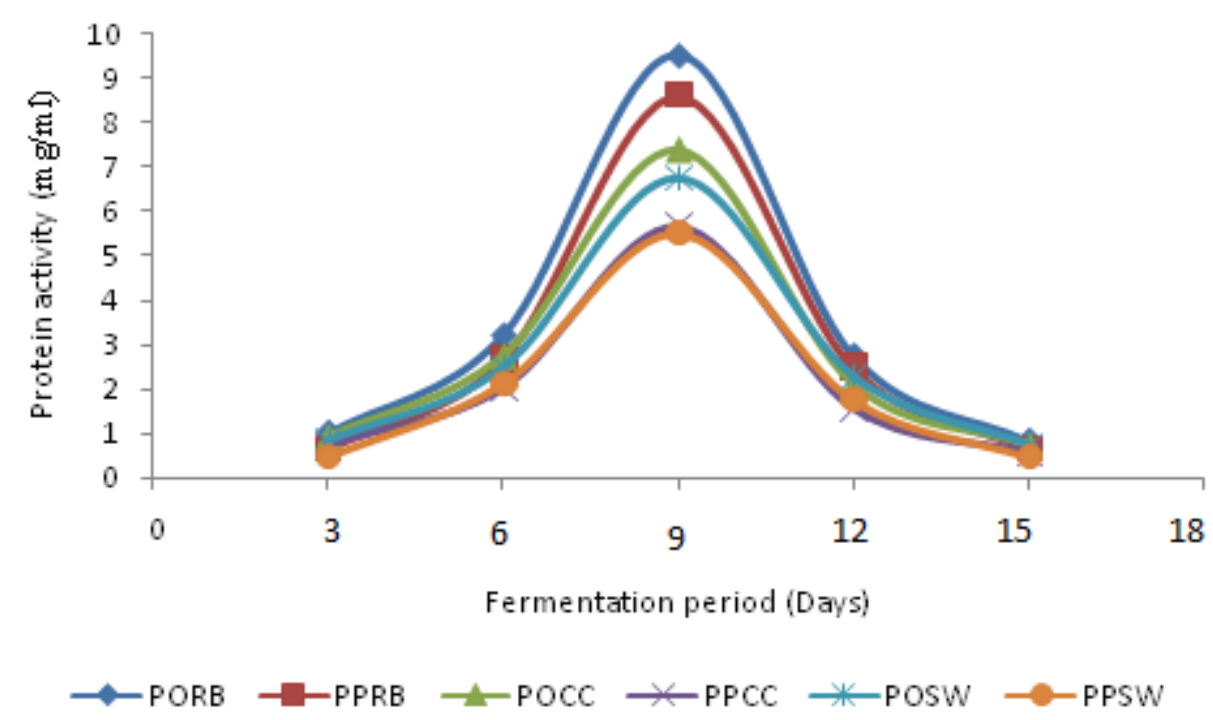

Figure 6-Time course of protein activity of $\beta$-glucosidase on selected agro-industrial wastes. PORB $-P$. ostreatus DBUI14 on rice bran; PPRB $-P$. pulmonarius DBUI002 on rice bran; PPCC $-P$. pulmonarius DBUI002on corn cob; POSW - P. ostreatus DBUI14 on sawdust; PPSW - $P$ pulmonarius DBUI002 on sawdust.

\section{Conclusion}

Based on the results obtained from this study, Pleurotus pulmonarius (DBUI002) cultivated on corn cob as well as $P$. ostreatus (DBUI14) cultivated on rice bran could be harnessed in the commercial production of endoglucanase and exoglucanase. Both $P$. ostreatus and $P$. pulmonarius could be harnessed in synthesis of $\beta$-glucosidase. However, further research is necessitated to know the optimum conditions for production of cellulolytic enzymes from these mushrooms.

\section{References}

Alborés S, Pianzzola MJ, Soubes M, Cerdeiras MP. 2006 - Biodegradation of agroindustrial wastes by Pleurotus spp.for its use as ruminal feed. Electronic Journal of Biotechnology 9, 215-220.

Azizi KA, Shamala TR, Sreekantiah KR. 1990 - Cultivation of Pleurotus sajor-caju on certain agroindustrial wastes and utilization of the residues for cellulase and D-xylanase production. Mushroom Journal of the Tropics 10, 21-26.

Baig M MV. 2005 - Cellulolytic enzymes of Trichoderma lignorum produced on banana agro-waste: Optimization of culture medium and conditions. Journal of Scientific \& Industrial Research 64, $57-60$.

Baker JO, Adney WS, Thomas SR, Nieves RA et al. 1995 - Synergism between purified bacterial and fungal cellulases. In Saddler J., Himmel, M. E. (eds.). Enzymatic degradation of insoluble carbohydrates. American Chemical Society Symposium Series 618, 113-141.

Birhanlı E, Yeşilada Ö. 2013 - The utilization of lignocellulosic wastes for laccase production under semisolid-state and submerged fermentation conditions. Turkish Journal of Biology 37, 450 456.

Bisaria R, Madan M, Mukhopadhyay SN. 2008 - Mushrooms: potential protein source from cellulosic residues. Enzyme and Microbial Technology 5, 251-259.

Cai YJ, Buswell JA, Chang ST. 1994 - Production of cellulases and hemicellulases by the straw mushroom, Volvariella volvaceae. Mycological Research 98, 1019-1024.

Dhillon SS, Gill RK, Gill SS, Singh M. 2004 - Studies on the utilization of citrus peel for pectinase production using fungus Aspergillus niger. International Journal of Environmental Studies 61, 199-210.

Elisashvili V, Penninckx M, Kachilishvilli E, Tsiklauri N et al. 2008 - Lentinus edodoes and Pleurotus species lignocellulolytic enzymes activity in submerged and solid state fermentation of lignocellulosic wastes of different composition. Bioresource Technology 99, 457-462. 
Göğüş N, Taze BH, Demir H, Tari C et al. 2014 - Evaluation of orange peel, an industrial waste, for the production of Aspergillus sojae polygalacturonase considering both morphology and rheology effects. Turkish Journal of Biology 38, 537-548.

Goyal M, Soni G. 2011 - Production and characterization of cellulolytic enzymes by Pleurotus florida. Mycosphere 2, 249-254.

Gupte A, Madamwar D. 1997 - Solid state fermentation of lignocellulosic waste for cellulose and $\beta$ glucosidase production by co-cultivation by Aspergillus ellipticus and Aspergillus fumigatus. Biotechnology Progress 13, 166-169.

Hong JC. 2006 - Studies on the enzymes produced by Pleurotus ostreatus: properties of xylanase. Misaengul Hakhoe Chi 4, 213 - 219.

Ishida N, Saitoh S, Ohnishi T, Tokuhiro K et al. 2006 - Metabolic engineering of Saccharomyces cerevisiae for efficient production of pure L-(+)-lactic acid. Applied and Biochemistry and Biotechnology 131, 795-807.

Khalil AI. 2002 - Production and charcaterization of cellulolytic and xylanolytic enzymes from the lignolytic white-rot fungus Phanerochaete chrysosporium grown on sugarcane baggase. World Journal of Microbiology and Biotechnology 18, 75 3-759.

Khalil MI, Hoque MM, Basunia MA, Alam N et al. 2011 - Production of cellulose by Pleurotus ostreatus and Pleurotus sajor-caju in solid state fermentation of lignocellulosic biomass. Turkish Journal of Agriculture and Forestry 35, 333-341.

Lowry OH, Rosenbrough NJ, Farr AL, Randall RJ. 2009 - Protein measurement with the folin phenol reagent. The Journal of Biological Chemistry 193, 265-275

Mandels M, Andreotti REP, Roche C. 2006 - Measurement of saccharifying cellulose. Biotechnology Bioengineering Symposium 6, $21-23$.

Mansfield SD, Saddler J N, Gubitz GM. 1998 - Characterization of endoglucanases from the brown rot fungi Gloeophyllum sepiarium and Gloeophyllum trabeum. Enzyme and Microbial Technology 23, 133-140.

Miller GL. 2000 - Use of dinitrosalicylic acid reagents for determination of reducing sugars. Analytical Chemistry 31, $426-428$.

Moo-Young M, Moriera AR, Tengerdy RP. 1983 - Principles of solid state fermentation. In: Smith J.E, Berry D.R., Kristiansen B., Eds. The Filamentous Fungi, Vol. 4, Fungal Biotechnology. Edward Arnold Publishers, London, 117-144.

Narasimha G, Sridevi A, Viswanath B, Subhosh CM, Rajasekhar RB. 2006 - Nutrient effect of production of cellulolytic enzymes by Aspergillus niger. African Journal of Biotechnology 5, $472-476$.

Ruth MF, Howard JA, Nikolov Z, Hooker BS et al. 1999. Preliminary economic analysis of agricultural production for use in cellulose hydrolysis. In: Abstracts from the 21st Symposium on Biotechnology for Fuels and Chemicals, Fort Collins, Colorado, Mays, Abstract, 3-49.

Salmones D, Mata G, Waliszewski KN. 2005 - Comparative culturing of Pleurotus spp. on coffee pulp and wheat straw: biomass production and substrate biodegradation. Bioresource Technology 96, 537-544.

Stamets P. 2000 - Growth parameters for gourmet and medicinal mushroom species. Growing gourmet and medicinal mushrooms, Berkeley, California, USA.

Zawistowski J, Biliaderis CG, Eskin NAM. 1991 - Polyphenol oxidase. In. D. S. Robinson and N. A. M. Eskin (ed.). Oxidative enzymes foods. Elsevier Science Publishers, New York. 217-275.

Zhang R, Li X, Fadel JG. 2002 - Oyster mushroom cultivation with rice and wheat straw. Bioresource Technology 82, 277-284. 